\title{
GeoGrid3D: a program to insert faults in 3D geological model for fluid simulation
}

\author{
Marcelo Kulevicz, Bartoszeck ${ }^{1 *}$, Alvaro Muriel Lima Machado ${ }^{2}$, Sidnei Pires Rostirolla ${ }^{3}$
}

\begin{abstract}
This paper has reported the use of geological and geophysical data into a 3D flow simulation model (gas). To adopt freeware software in flow simulation, we produced a program called GeoGrid3D. Our program is available with fault insertion features into ASCII 3D models. Also, it has other codification functions that change data for boast recognition (boast is the flow simulation freeware issued by the United States Department of Energy). We have developed the 3D reservoir grid and the structural framework model with data from outcrops of Permian sedimentary rocks and shallow seismic reflection. Analysis of geological facies in outcrops and their correlation with the stratigraphy are the methods used in 3D grid geological modeling and petrophysical properties. To demonstrate GeoGrid3D functions, we elaborated a main petrophysical model with supplementary three hypothetical tectonic faults playing. The gas saturation, after flow simulation, confirms that changing faults permeability inside the reservoir will change gas production in this model.
\end{abstract}

Keywords: boast; 3D modeling; Itararé Group.

Resumo GeoGrid3D: um programa de inserção de falhas em um modelo 3D de simulação de fluxo. Este artigo apresenta um exemplo de aplicação da integração de dados geofísicos e geológicos num modelo 3D para simulação de fluxo. O procedimento da simulação de fluxo foi realizado com um programa de livre distribuição chamado Boast, do Departamento de Energia dos Estados Unidos. Entretanto, foi necessária a geração de um programa, denominado GeoGrid3D, para a conversão dos valores de permeabilidade e também para a inserção de falhas no modelo de simulação. Dados de afloramentos de rochas sedimentares do Permiano, Grupo Itararé - Bacia do Paraná e seções sísmicas rasa de alta resolução foram utilizados para a estrutura e preenchimento de um modelo 3D para simulação. A correlação de propriedades petrofísicas, obtidas a partir de análises estratigráficas dos afloramentos, também foram inseridas no modelo. $\mathrm{O}$ modelo 3D contemplou quatro situações tectônicas com distintos comportamentos de propriedades petrofísicas onde ocorria presença de falhas. A resposta da saturação de gás após a simulação de fluxo confirma que alterações na permeabilidade das falhas, dentro de um reservatório, mudam de forma significante a produção de gás em rochas do modelo utilizado neste estudo.

Palavras-chave: boast; modelagem 3D; Grupo Itararé.

INTRODUCTION The simplest description of GeoGrid3D is: "a fracture insertion tool in 3D American Standard Code for Information Interchange (ASCII) geological model made for fluid simulation with Boast." This sentence explains the main problem, and the solution that we found was to develop our own software. Fluid simulation software uses mainly numerical models of porosity and permeability to describe reservoir rocks. Several kinds of data are accepted to build these models used in fluid simulation: seismic, well correlation, analog outcrops, and hypothetical concepts.
However, the incorporation of faults inside these models is not an established process. These faults are represented mainly by surfaces or with abrupt values change in petrophysical properties. In flow simulation, tectonic features form barrier or high permeability units, or both along geological time, which have a direct influence in hydrocarbon mobility. The success or failure of a prospect may be related to the tectonic framework of the reservoir. When inserting various faults scenarios (fault facies) into the same reservoir, geological model is a helpful tool to cut risk.

\footnotetext{
'Departamento de Geologia da Universidade Federal do Paraná - UFPR, Curitiba (PR), Brasil. E-mail: mbartoszeck@gmail.com ${ }^{2}$ Departamento de Geomática da Universidade Federal do Paraná - UFPR, Curitiba (PR), Brasil. E-mail: alvaroml@ufpr.br ${ }^{3}$ HRT Oil \& Gas, Rio de Janeiro (RJ), Brasil. E-mail: sidnei.rostirolla@hrt.com.br

*Autor correspondente
} 
Freeware programs (BOAST - DOE Contract $\mathrm{n}^{\circ}$ DE-AC19-80BC10033, 1982 and Deutsch 1999) and complementary commercial softwares are a way to use low cost PCs (a good PC in the range of U\$1000,00 - 2012 list price) in fluid flow simulation and 3D geological modeling within petroleum reservoirs. BOAST is a $3 \mathrm{D}$, three-phase black oil simulator developed to support fluid simulation projects of the US Department of Energy. It simulates Darcy flow in three dimensions and assumes reservoir fluids described by three isothermal fluid phases: oil, gas, and water. The fluid composition is constant with physical properties that depend only on pressure. The use of 3D systems for modeling rocks are common with commercial programs, such as gOcad $^{\mathrm{TM}}$, EarthVision ${ }^{\circledR}$, Maptek Vulcan ${ }^{\mathrm{TM}}$, Petrel ${ }^{\circledR}$ (the last one is used in this article), among others. The modeling process varies but the results are in general: surfaces (Mallet 1992), voxels, or tetra-hedralised forms to represent geological framework structures. Numerical reservoir models are the essential input for flow simulation. This is usually performed on large computer data centers and very expensive programs suites. However, universities and independent researcher's reality are very different from big oil companies. Thus, the developments of simple programs for geological modeling and fluid flow simulation are very important in the academy.

A 3D geological model may contain surfaces to represent the stratigraphic framework (like beds limits) and faults to represent the tectonic. These faults can be used as a conditional bias artifact in the petrophysical properties interpolation process. In nature at a reservoir scale, faults normally occur after or during sedimentation process. Therefore, it is reasonably to consider inserting reservoir scale faults just after petrophysical interpolation phase, assuming in this petrophysical only the syn-sedimentary aspects. Large faults affect sedimentation (growth sequences lateral faults) and can change the future reservoir before diagenesis. In this article we have simplified the 3D geological model within faults only in reservoir scale and newer to the sediments consolidation.

The program GeoGrid3D was developed in Delphi $^{\circledR}$ and runs on Windows ${ }^{\circledR}$ machines. It has input and output files with ASCII codification. The program is free and is available. Please contact the author.
FLUID SIMULATION AND FAULTS Fluid simulation in petroleum reservoirs is developed to optimize well productivity, to match production data, to update geological models, to preview and update the distribution of flow units, to evaluate infill opportunities (Purvis et al. 2002), and to compare results from analog models. The flow and mass transfers in underground reservoirs are complex, but better modeled with numerical simulations by using entropy (Delay \& Lamotte 2000). Current literature (Iske \& Randen 2005) deals with new developments and advances on mathematical methods and modeling including numerical reservoir simulations, which are better discussed. In our work, the fluid simulation was very simple and used default values from Boast examples, changing only the properties of grid and well location.

Some aspects of incorporating faults properties to fluid simulation models were discussed in the work carried out by Al-Busafi et al. (2005). These authors compared results for thickness and two-phase fluid flow modeling within the faults in simplified reservoir models. Faults can severely compartmentalize reservoirs affecting petroleum recovery (Corrigan 1993). Reservoir performance predictions can be more accurately by modeling the fluid flow impact. Therefore, it is likely the ability to insert multi-scenarios of faults within the 3D simulation model. This various hydrological behaviors can be simulated by changing values of permeability and/or porosity in faults and surroundings.

Direct laboratory measurements of relative permeability from cataclastic fault rocks, using gas as fluid, suggest that absolute permeability values can be overestimated (Al-Hinai 2007). A better analysis of the reservoir can be achieved with simulations taking into account over and underestimated petrophysical values of the rocks affected by faults. In order to do this routinely, software tools, which can easily modify properties at faults influence area, using always the same model as a base, are necessary.

GEOGRID3D STRUCTURE Basically, the program reads and writes ASCII files, which means that any text editor can be used to generate and modify the files. The program interface consists of cascade menus that open windows for specific input of parameters and files location. Each function has its own window, but secondary windows can be required for detailed parameters. There are eight conversion functions from the main menu. The idea 
was to use BOAST, $\mathrm{Gslib}^{\odot}$ and Eclipse $^{\odot}$ file formats that are usual for most people who work with 3D geological modeling and fluid simulation of reservoirs. BOAST has a graphical user interface called Edboast, which is the name that we chose for its files used in GeoGrid3D. Detailed description of each function can be found in the user guide. The main functions are:

- Eclipse $^{\mathcal{O}}$ to Edboast - converts Eclipse ${ }^{\mathcal{O}}$ properties to the Boast ones;

- Edboast to Eclipse $^{\odot}$ - converts the output files results of Boast simulation to Eclipse $^{\mathfrak{O}}$;

- Eclipse $^{\odot}$ to IJK - converts Eclipse ${ }^{\odot}$ properties to a IJK file;

- IJK to Eclipse - returns IJK files to Eclipse $^{\odot}$;

- GSLIB to Edboast - converts gslib (XYZ) files to Edboast;

- Edboast to XYZ - returns the simulation output file to the XYZ format;

- Edboast to IJK - converts the output file of simulation to IJK format;

- Edboast to GSLIB - converts the input format to the GSLIB (XYZ) format.

\section{GEOGRID3D HISTORY The GeoGrid3D} program was developed to clear up a problem. We have worked on an extensive (Bartoszeck et al. 2008) modeling task with shallow seismic and outcrops data and desire to complete this study with an experimental fluid simulation. To solve this, we required a simulation software and we did not have the necessary research funds to buy a commercial one. The Boast program fixed this issue because it is free. However, it created another issue: Boast input/output formats of files are very specific and laborious to prepare. We also have plenty of data. The first idea was to write simple scripts to convert our modeled data to Boast. However, we noted the possibility to introduce some functions that could be helpful in fluid simulation. These functions insert fault(s) and take over conditional values along it(s) surface before simulation into Boast. The fault function is easy to understand. It is placed in the numerical model faults surfaces (Fig. 1) and defines what will happen with the property value in affected voxels.

The conditional function along the fault contemplates differential tectonic influence in several lithologies. For example, the same fault that crosses sandstones and mudstones will have within its deformation different values of permeability or porosity. This happens due to petrophysical properties of the rocks (Fig. 2). To get to this specific variation, we developed a mathematical function that examines values around a search area. If the voxel is crossed by a fault, an analysis will be carried out and the value will probably be conditioned, according to the rules settled in GeoGrid3D. This function uses any 3D numerical grid (porosity or permeability for example) and faults in ASCII. Both need to be in the same coordinate system, such as ijk or xyz.

The values tests use an ellipse search around the voxel crossed by a fault (Fig. 3). The list with search results will be submitted to a set of rules that will determine the numerical transformation. The
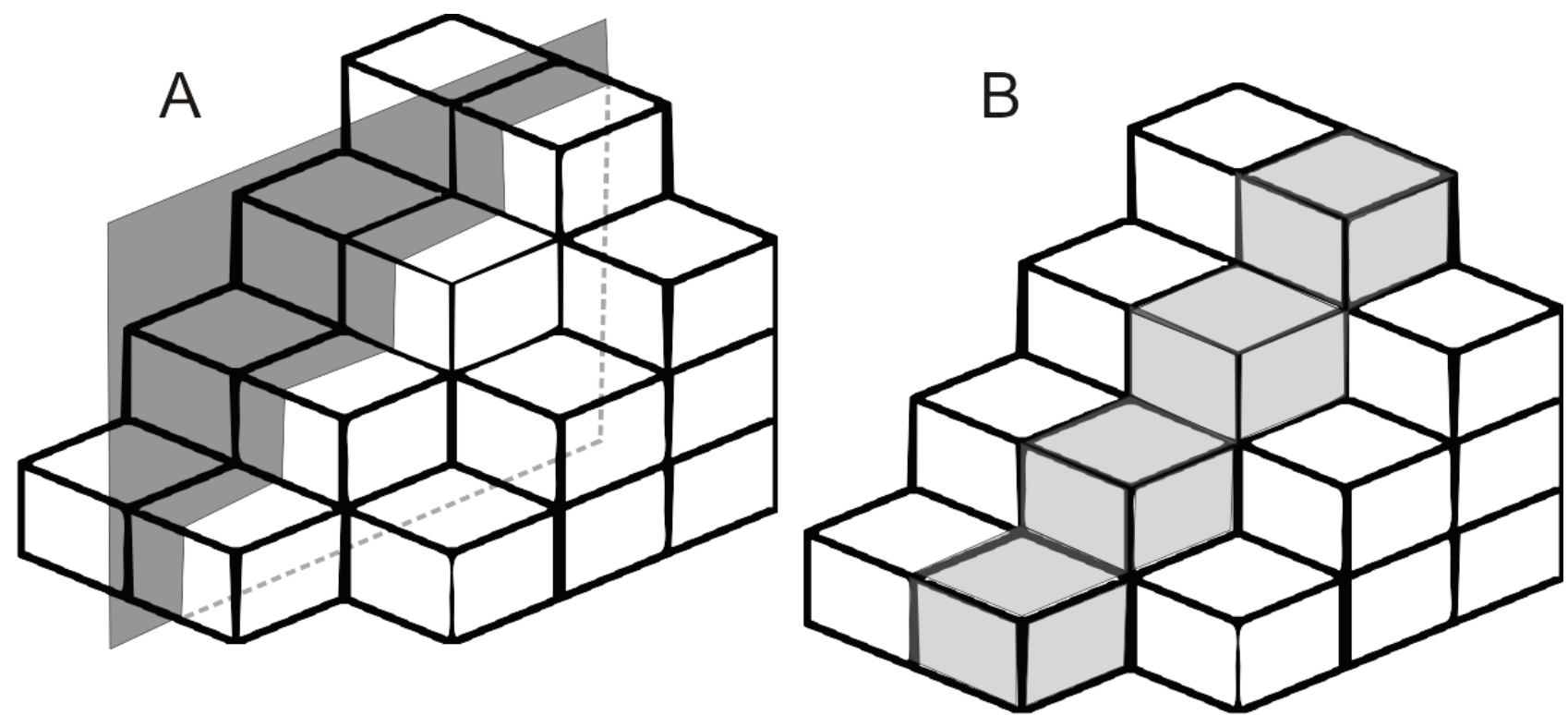

Figure 1 - (A) Vertical fault crossing a 3D model; (B) Voxels with values properties changed by the fault in A. 


\section{Fault/Fracture}

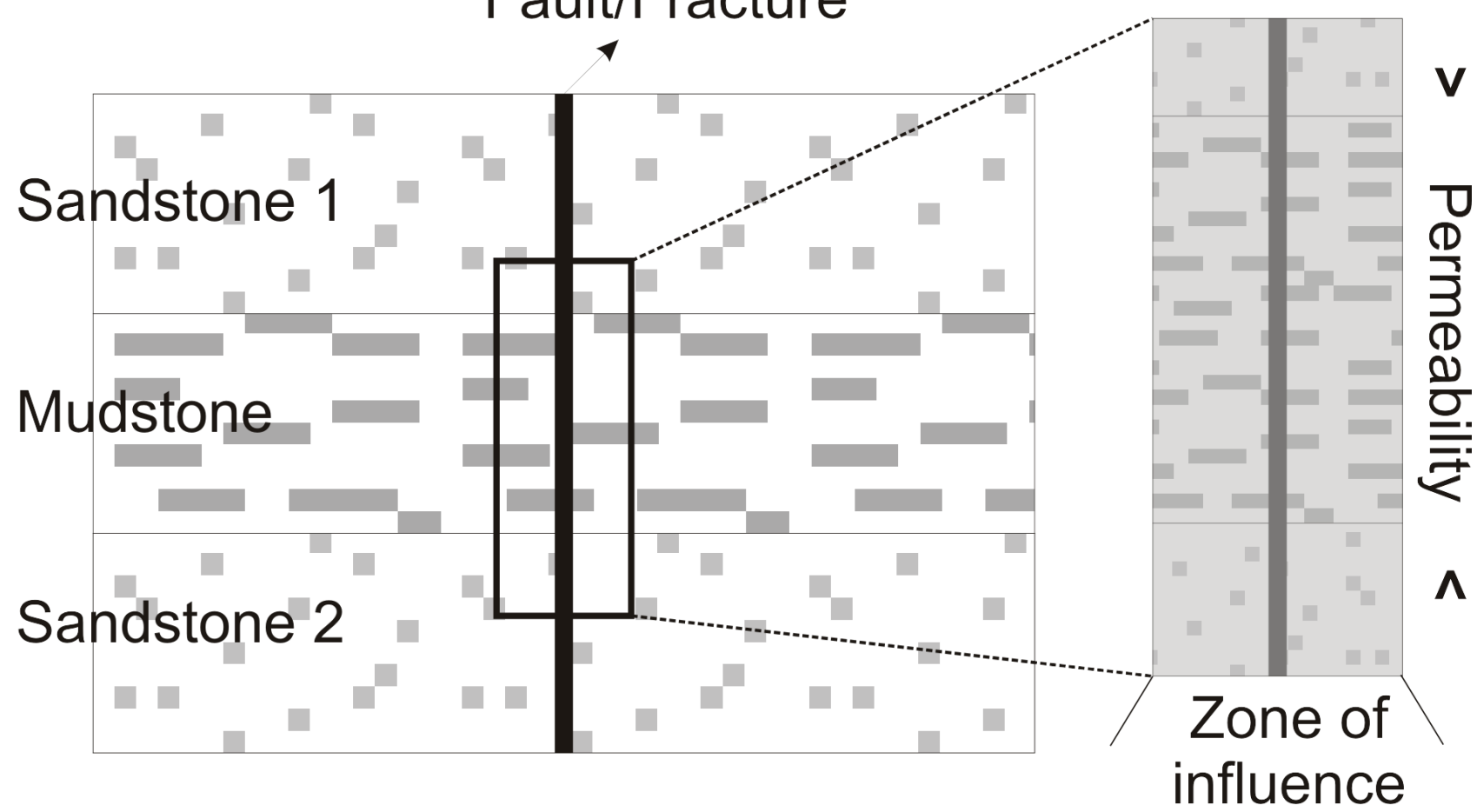

Figure 2 - Hypothetical geological section crossed by a fault in the center. Fault zone of influence detail for differences in permeability (> for greater values) along the same fault, but in different rocks.
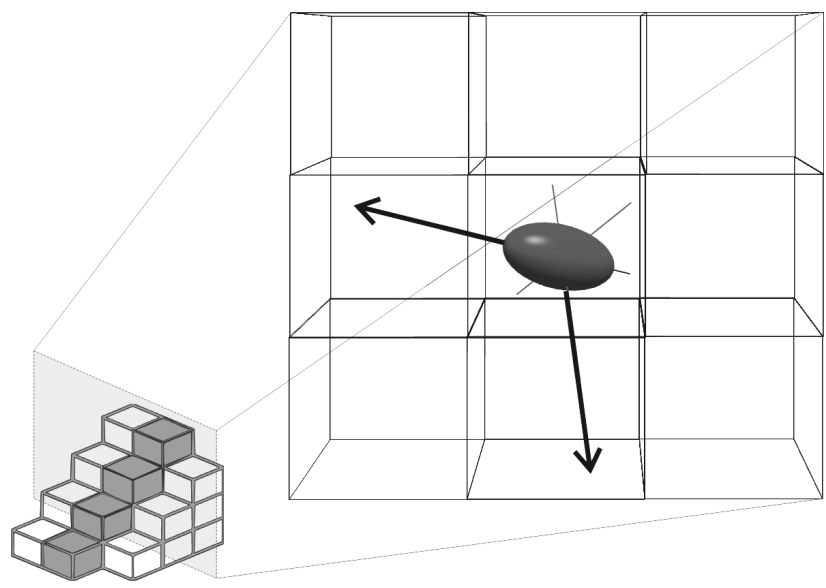

Figure 3 - Example of a profile on one 3D model and the ellipse search with axes of two voxels.

search area size is measured in voxel units. A value of 0.5 voxel means that only the ones crossed by the fault will change. Therefore, the search area needs to be set with integers greater than one to affect larger widths around the fault plane. It is important to take into account the voxel sizes to avoid making mistakes over the size of the fault influence.

It is a common sense that faults growths are a succession of events. Starts with widths of few millimeters into zones up to several tenths of centimeters and finally band faults up to several tenths meters of deformation are quite common (Aydin \& Johnson
1978). Faults that have considerable influence in petrophysical values can be represented with large zone of influence. For complex zoning in these huge faults, it is necessary a sequence of buffer functions, for instance, a fault influence with $8 \mathrm{~m}$ in each side inside a $3 \mathrm{~m}$ resolution $3 \mathrm{D}$ model. However, the first $1 \mathrm{~m}$ permeability $(500 \mathrm{mD})$ is greater than the next $3 \mathrm{~m}$ $(250 \mathrm{mD})$, which are also greater than the rest of influence $(100 \mathrm{mD})$. This specific fault zone can be done according to three rules. The first arranges the smallest permeability into all $8 \mathrm{~m}$ (3 voxels), the second takes medium permeability beside the $4 \mathrm{~m}$ ( 2 voxels) and, finally, the last rule changes values around the fault (1 voxel). Since each rule is independent routine and uses the prior data as input, the changes made by the first one will remain to all voxels not affected by the second one (Fig. 4).

Voxel size's impact resolution along faults paths. Low resolutions in linear faults obtain a "ladder" aspect. But, the high resolution will affect computing time (Fig. 5). A function in GeoGrid3D allows redefining the grid resolution using the nearest neighborhood method. This simple interpolation process applied to previous regularized data affects very little the distribution of values. Reducing voxel sizes before fault introduction can be very useful to gain a better definition. 


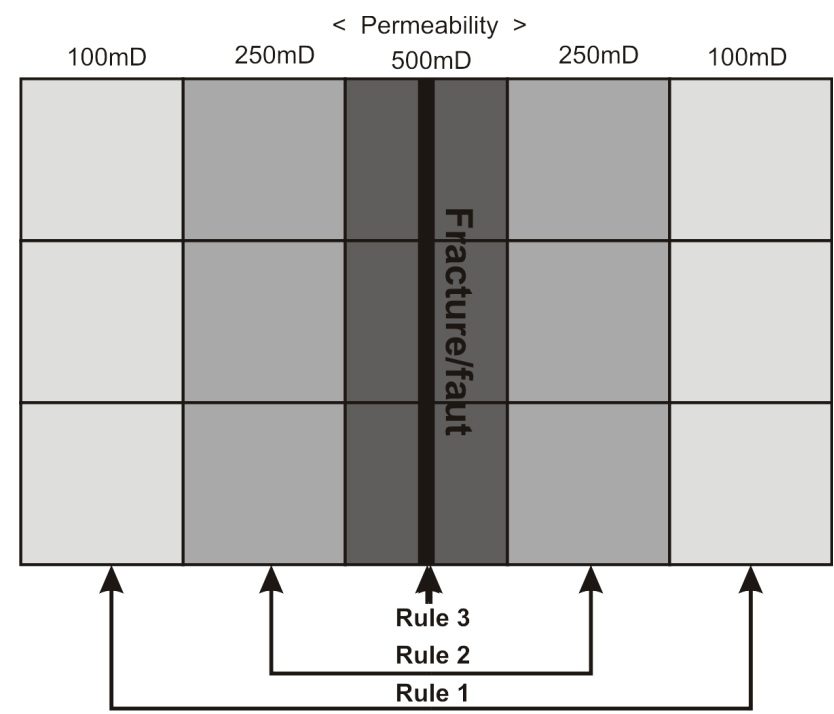

Figure 4-Example of buffer application for different fault offset influence. Increasing influence zones from the center to far away the fault. Total influence with 8 $m$ and model with $3 m$ of resolution.

TEST WITH REAL DATA This test uses highresolution analog modeling data prepared for a flow simulation (gas). High-resolution seismic reflection, outcrop information and shallow wells were used in an integrated framework of geological modeling (Fig. 6). The study area is located near Curitiba city (Southern Brazil), where rocks, Itararé Group - Paraná Basin, outcrop. These rocks have good analog relationship to real hydrocarbon reservoir from the same basin. The first commercial gas accumulation of this basin was drilled in rocks from Itararé Group (Campos et al. 1998). The Paraná Basin is a wide sedimentary site in South America covering 1.8 million square $\mathrm{km}$. The stratigraphy reaches thicknesses of $7.5 \mathrm{~km}$ with deposits from the Ordovician to lower Cretaceous, when a huge event of basalt volcanism completed the basin evolution. The Itararé Group consists of upper Carboniferous-Lower Permian glaciogenic deposits with different arrangements of massive shales, diamictites, rhythmites, and fine to medium grained sandstones with cross-stratification.

The 2D seismic, acquired with gun fire seismic source proved to be helpful to build the surfaces for a volumetric model. The seismic lines lengths are between 250 and $700 \mathrm{~m}$ and about $200 \mathrm{~m}$ depth.

Seismic data were interpreted for traces that represent faults and horizons (Fig. 7). The data quality are far from good, but they still have some horizons related to the stratigraphy and some weak signal zones related to faults.

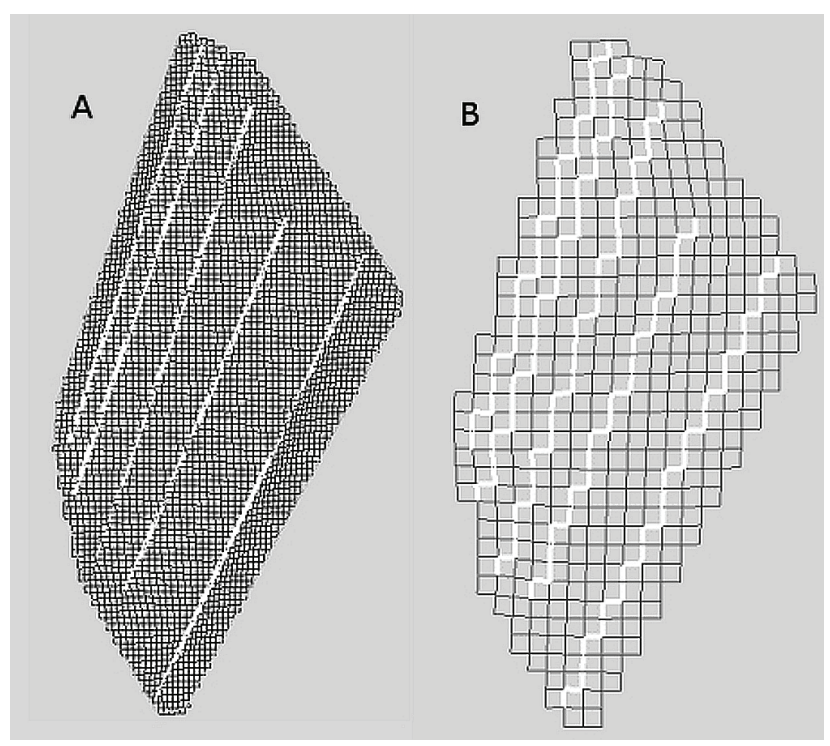

Figure 5 - Resolution influence in fault path. (A) High resolution model; (B) Low resolution model. Both models use the same faults.

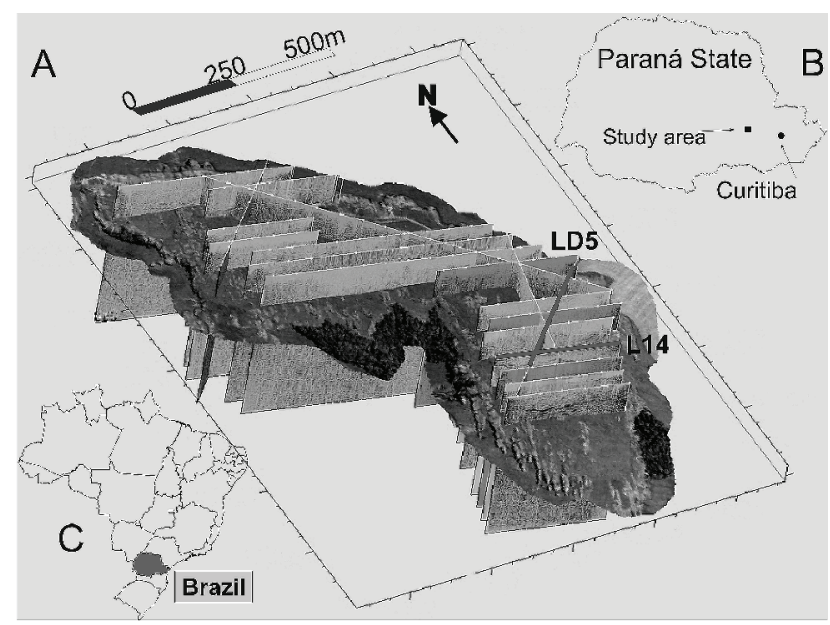

Figure 6-(A) Schematic figure of seismic lines array on aerial photography (1:10000) and two enhanced seismic lines; (B) Location of the study area in the Paraná State; (C) Location of Paraná State in Brazil.

The framework surfaces, defined by the seismic in two-way time, are roughly converted to depth by a constant value of $2,000 \mathrm{~m} / \mathrm{s}$. This conversion is based on average refraction velocities acquired on the field. The framework was loaded into geological modeling software (Petrel 2009). The voxels created in the software were filled with petrophysical values, using the stochastic modeling. These values were obtained in laboratory measurements of outcrops samples. The final simulation model has $19 \times 36 \times 13$ IJK and 9,000 active voxels. The depth of top reservoir is settled to $1,200 \mathrm{~m}$ and each voxel has constant sizes of $10 \times 10 \times 3 \mathrm{~m}$. To run the simulation, five 


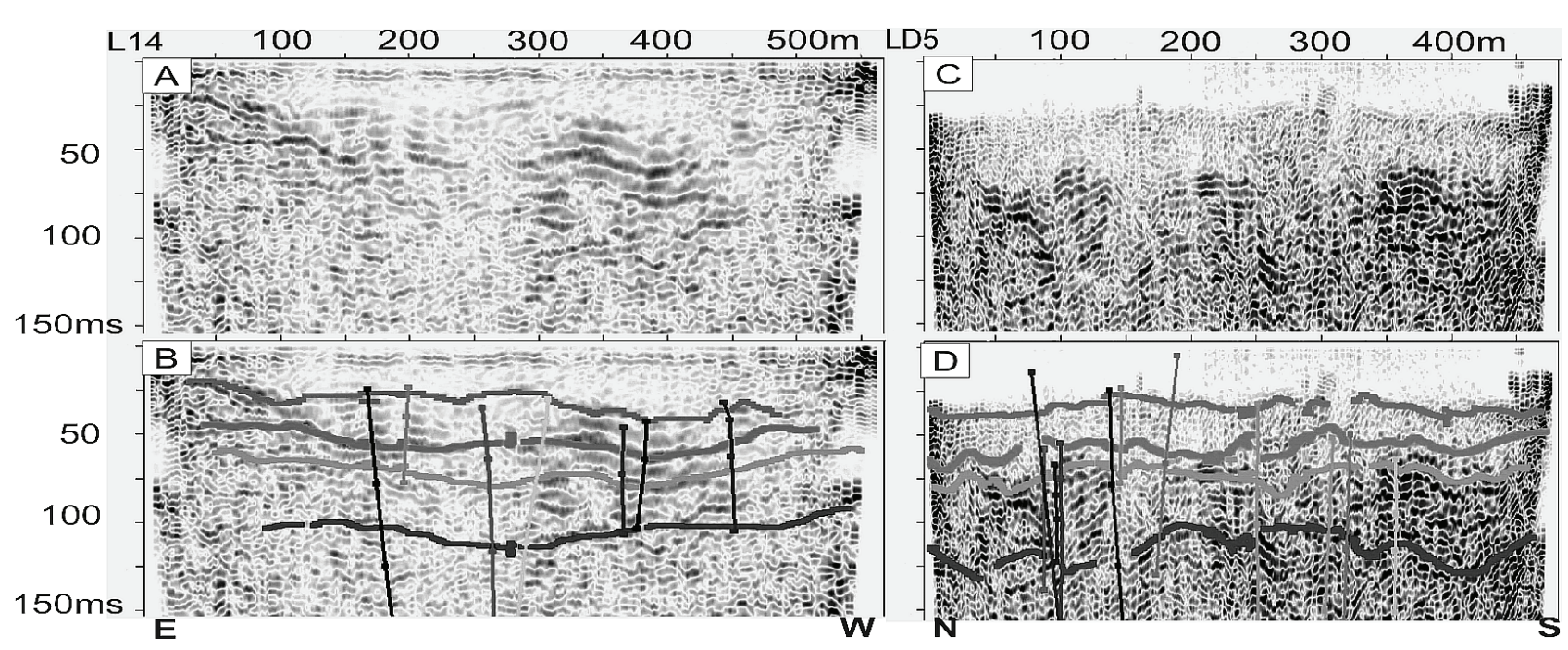

Figure 7 - (A) Seismic line L14; (B) L14 with interpretation; (C) Seismic line LD5; (D) LD5 with interpretation. Locations of both lines are depicted in Fig. 6.

productive wells are located around the model near fourth corners and in the center (Fig. 8).

The simulation parameters are based on a gas reservoir with aquifer influx ("example 5.6" inside the BOAST models). We have defined four scenarios to evaluate the impact of faults with different hydraulic comportment. These cases use exactly the same origin: the model "without faults". The other three models are: barrier, intermediate, and high faults. The faults are exactly the same, just changing the rules, in each case as: 1,100 , and $500 \mathrm{mD}$, respectively. The zone of influence for all was 1 voxel. After simulation, these four cases showed different results in gas depletion. To compare the results, we sliced the four models in the same place with colors representing the gas saturations in Fig. 9.

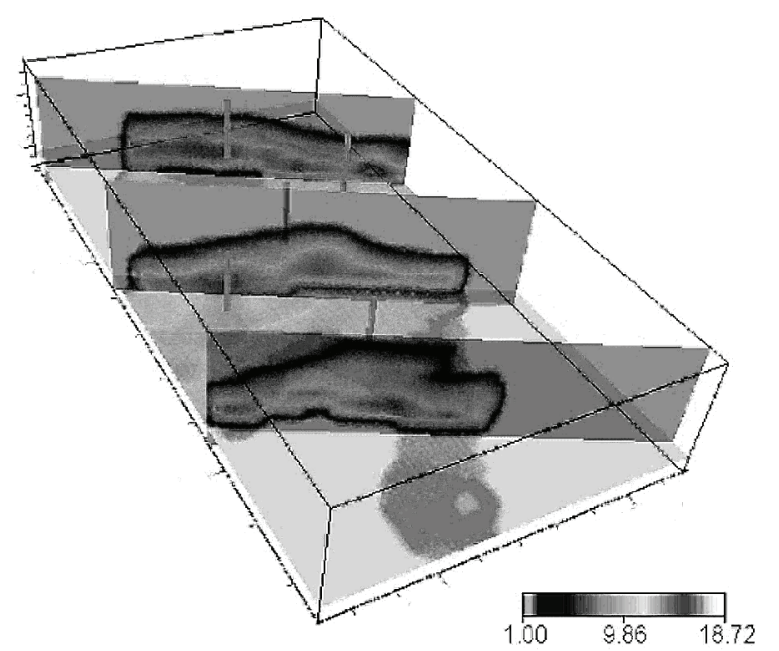

Figure 8-3D model of porosity with the location of five wells used in the fluid simulation.
We assume that less gas saturation in the reservoir model indicates more production. The start of the simulation sets all those slices as in Fig. 9 with $100 \%$ of gas saturation. The porosity model was the same for the four scenarios. After the simulation, all four models produced gas, because all of them have depletion. However, different results are clearly noticed by color variation in each model. Low gas saturation (dark colors) in the models with 100 and $500 \mathrm{mD}$ delineates the faults planes more than the models without faults and as barriers. These last models do not enhance fault planes with colors of gas depletion. Other production aspect is the bigger depletion area for "high" model. Finally, the model with barrier faults simulates less depletion than without faults. Fluid simulation for gas production in one reservoir of these characteristics is probably the best of not having faults than acting as barriers.

CONCLUSIONS We have developed a program useful for geological modeling and flow simulation studies that use ASCII data and BOAST simulator. We have showed one qualitative test with real data. 3D numerical modeling can generate a very large amount of data. However, these numerical models are not always ready to a flow simulation. A program that performs as an intermediate tool can be helpful to integrated flow simulation studies. Some features inserted into the program enlarge the results and possibilities of simulation models. This is the first published version of the GeoGrid3D, and we expect bugs and 


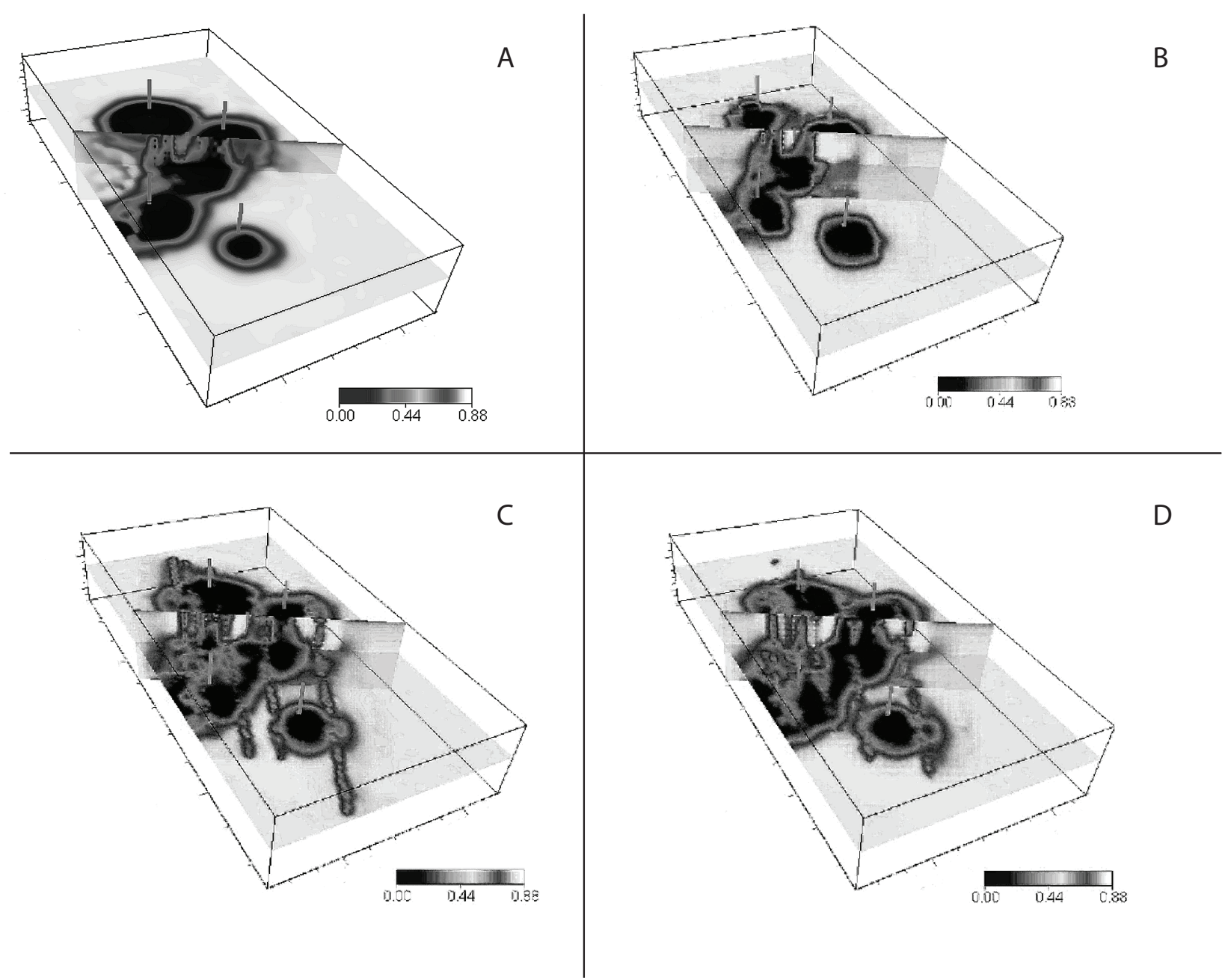

Figure 9 - Slices of gas saturation after the simulation. (A) Model without faults; (B) Model with barrier faults; (C) Model with intermediate faults; and (D) Model with high faults.

bad-functions. However, we also intend to enhance the program with new functions to obtain better models for simulations in the near future.

ACKNOWLEDGMENTS The research work for this paper was carried out as part of Bartoszeck et al. (2008). thesis with scholarships from the Brazilian National Research Council (CNPq). We are also grateful to the Petrophysical and Basin Analysis Laboratory from the Federal University of Paraná Brazil (LABAP) for using in its facilities computers, softwares, and research.

\section{References}

Al-Hinai S., Fisher Q.J., Al-Busafi B., Guise P., Grattoni C. A. 2007. Marine and Petroleum Geology, doi:10.1016/j. marpetgeo.2007.07.005.

Aydin A. \& Johnson A.M. 1978. Development of faults as zones of deformation bands and as slip surfaces in sandstones. Pure and Applied Geophysics, 116:931-942.

Bartoszeck M.K., Rostirolla S.P., Campos A.F., Machado A.M.L. 2008. Modelagem volumétrica e simulação de fluxo em arenitos análogos a reservatórios profundos: exemplo da Formação Campo Mourão, Bacia do Paraná (Volumetric modeling and flow simulation em deep reservoir analogs sandstone: Campo Morão
Formation, Paraná Basin example). Revista Brasileira de Geociências, 38:128-139.

Campos L., Milani E., Toledo M., Queiroz R., Catto A., Selke S. 1998. Barra Bonita: a primeira acumulação comercial de hidrocarboneto da Bacia do Paraná (Barra Bonita: The first commercial hidrocarbon accumulation of Paraná Basin). Brazilian Petroleum Institute - IBP. In: Presentantion paper in Rio \& Gas Conference. Rio de Janeiro, Brazil.

Corrigan A.F. 1993. Estimation of recoverable reserves: the geologistsjob. In: Parker J. R. (Ed.) Petroleum Geology of Northwest Europe: Proceedings of the 
Fourth Conference, The Geological Society London, p. 1473-1482.

Delay F. \& Lamotte J. 2000. Numerical simulations of geological reservoirs: improving their conditioning through the use of entropy. Mathematics and Computers in Simulation, 52:331-331.

Deutsch C.V. 1999. Reservoir modeling with publicly available software. Computer \& Geosciences, 25:355-363.

Earthvison(C. 2008. Dynamic Graphics, Inc. Alameda, California, USA. Disponível em: http://www.dgi.com/ earthvision/evmain.html. Acesso em: 03/2008.

Iske A. \& Randen T. 2005. Mathematical methods and modeling in hydrocarbon exploration and production. New York, Springer Berlin Heidelberg, 447 p.
Mallet J.L. 1992. GOCAD: a computer aided design program for geological applications. In: Turner K. (Ed.) Three-Dimensional Modeling with Geoscientific Information Systems. NATO ASI Series. p. 123-142.

PetrelC. 2009. Schlumberger Limited. Houston, US. Disponível em: http://www.slb.com/content/services/ software/geo/petrel/index.asp?. Acesso em: 03/2009.

Purvis K., Kao J., Flanagan K., Henderson J., Duranti D. 2002. Complex reservoir geometries in a deep water clastic sequence, Gryphon Field, UKCS: injection structures, geological modeling and reservoir simulation. Marine and Petroleum Geology, 19:161-179.

Manuscrito ID 14512 Recebido em: 05/06/2009 Aprovado em: 23/04/2012 